origin than aberrant ovarian structures. Dermoid elements and traces of Wolffian rests may be associated with these tumours. The presence of aberrant structures of this kind in various parts of the pelvis and its vicinity, enable us to understand the occurrence of recurrent ovarian cystomata and of the other curious phenomena above mentioned. What is the condition of such structures after the removal of both ovaries? We know that they are then exposed to the stress of enormous formative activitythe so-called compensatory hypertrophy. In these circum. stances the limits of physiological activity may easily be overpassed, and when the process becomes pathological it eventuates in the formation either of non-malignant cystoma or of a malignant tumour. Thus may be explained the extraordinary frequency of malignant disease after the removal of both ovaries, to which I have elsewhere called special attention. - I am, Sirs, yours faithfully,

Clifton, Bristol, Nov. 2nd, 1903.

W. Roger WiLliams.

\section{EROSIVE GASTRIC ULCERATION.}

\section{To the Editors of THE LANCET.}

SIRS,-In April, 1902, I exhibited at the Kidderminster Medical Society a girl upon whom I had successfully operated for gastric erosion. The notes of the case were given in your report of the meeting in THE LANCET of April 26th, 1902 , p. 1185. I was very much interested to read the case published by my friends Sir Dyce Duckworth and Mr. H. T. Butlin and also your annotation thereon in your issue of Oct. 17th. I thought that it might be interesting to your readers to know that $I$ am able to state that the patient has had no return of her symptoms.

I am, Sirs, yours faithfully,

J. LIONEL STRETTON,

Oct. 20th, 1903. Senior Surgeon Gidderminster In and Children's Hospital.

\section{THE DE NOVO ORIGIN OF BACTERIA.}

To the Editors of THE LANCET.

SIRs, - In the course of his paper on the De Novo Origin of Bacteria in THE LANCET of Oct. 31st, p. 1220, Dr. H. Charlton Bastian refers to a signed article of mine on Leprosy which appeared in the Quarterly Revien for April, 1903, and from which he quotes. He contends that the verdict given by the Leprosy Commissioners in their report (Calcutta, 1893) was perfectly logical and quite explicable in accordance with known facts. I hope you will allow me to quote a little more at large from my article. I wrote: "Some years ago the Royal College of Physicians of London, in a report on the Mode of Origin and Spread of Leprosy, unfortunately expressed the opinion that it was not contagious. More recently the Leprosy Commissioners in India came to the conclusion that the infections nature of the disease had been finally established by the discovery of the bacillus and stated - that the disease was to be classed among the contagious diseases, the influence of contagion being as small as, or even rather less than, in the case of tuberculosis.' They also concluded there was no evidence that leprosy in India was hereditarily transmitted from parent to child and, further, that neither the form of diet nor the sanitary environment of the individual had any specific action in the causation of leprosy. At the same time, the Commissioners added that 'it is probable that bad hygienic surroundings, deficient or improper food, poverty, exposure, and such diseases as sypbilis are all factors of great importance in reducing the vital powers of the organism and rendering it more susceptible to attack.' The evidence pointed inevitably to the conclusion that leprosy is an infective contagious disease. But strangely enough, the Commissioners in their final summing up expressed the opinion that leprosy, in the great majority of cases, originated de novo. A critic has well said that this conclusion was extraordinary and contrary to the experience of those who had given special attention to the subject in leprous countries. It was all the more extraordinary, I added, seeing that the Commissioners advocated voluntary isolation. Further on in their report the Commissioners remark that both leprosy and tuberculosis are contagious in an equal and minimal degree." I leave it to the reader to judge for himself as to the logic of such reasoning. I would recommend him to read the report of the Leprosy Commission, and also, if I may venture to say so, my Quarterly
Revien article, wherein he will find a succinct survey of leprosy as a whole.

I regret that Dr. Bastian should consider my attitude in the matter intolerant because it clashes with his views on the de novo origin of various diseases. I quite thought the de novo theory had gone by the board long ago. I regret it all the more as Dr. Charlton Bastian was one of my clinical teachers at University College Hospital. I learnt from him important facts at the bedside, for which $I$ am ready to express my indebtedness. On the other hand, I cannot allow my esteem for him to stifle my own honest beliefs on certain points.-I am, Sirs, yours faithfully, George Pernet,

Assistant to the Skin Department, University College Hospital; English Editor of Lepra.

Upper Gloucester-place, N.W., Nov. 3rd, 1903.

\section{THE SOCIETY OF MEDICAL PHONO- GRAPHERS.}

To the Eaitors of THE LANCET.

SiRs,-May we be permitted as president and officers of the Society of Medical Phonographers to bring the continued existence of the society and its usefulness under the notice of any practitioners or students of medicine who make use of shorthand? Of late the society has not come much under the notice of the profession, but its work continues. Its organ, the Phonographic Medical Record, is published monthly and affords the means of obtaining familiarity with medical shorthand, together with definite information on practical medical subjects. The society has also issued a series of small original works in lithographed shorthand with the same object, as well as an extensive vocabulary of convenient outlines and guides to the use of shorthand both by the student and the practitioner. It has also held periodical examinations for students in order to encourage their acquisition and use of shorthand.

The invaluable aid which it can give in medical work, practical and theoretical, in case-taking and note-making, is realised by all who have used it, as it cannot be by others, and the importance of its acquisition before medical studies are commenced is so great that the society has endeavoured by every means to encourage this. But many practitioners who make constant use of shorthand have acquired it long after being engaged in practice. To all, students and practitioners alike, the society is open and its members are ready to give all possible help to those who are endeavouring to obtain the assistance of this time-saving art. The subscription to the society is very small, amounting only to $5 s$. per year for students and $7 \mathrm{~s}$. $6 d$. for practitioners. The honorary secretary, Dr. Fletcher Beach, will be glad to give any further information and to receive applications for membership.

We are, Sirs, yours faithfully,

DAVID FerRIER, President

W. Thomson, C.B., $\}$ Vice-Presidents.

W. $\mathrm{R}$ GOWERS,

G. Srms Woodhead. Members of Council.

Norman Porritt, Treasurer.

FLETCHER BEACH, Secretary,

Nov. 6th, $1903 . \quad$ Winchester House, Kingston-hill, Surrey

\section{THE RELATION BETWEEN THE SIZE OF THE CHILD AND THAT OF THE PELVIS.}

To the Editors of THE LANOET.

SIRS,--The perusal of the leading article in THE LANCET of Oct. 3rd, p. 963, in which you comment on my paper published in the issue of Sept. 26th, p. 885, makes it plain that I have so expressed myself as to appear to claim more for the law I enunciated than I had any intention of doing. I do not seem to have made the heading clear. You remark that I enunciate a "law by which the size of the child is to be determined." What I wrote was "a law by which the size of the child is determined." The former appears to imply a process by which a man may infer the size of the child in a particular case from that of the mother's pelvis; the latter was intended to draw attention to an orderly working of nature in the average, 